\title{
Perencanaan asuhan keperawatan pada pengetahuan dan sikap perawat
}

\author{
Syifa amalia br ginting \\ Syifasamsung42@gmail.com
}

\section{Latar Belakang}

Pengetahuan dan sikap yang benardalam memenuhi kebutuhan psikologis dan spiritual klien terminal sangat penting dikuasai oleh perawat professional dalam memberikan asuhan keperawatan, sehingga tujuan dalam memberikan asuhan keperawatan yang holistik kepada klien tercapai.

Di dalam perencanaan asuhan keperawatan meliputi pengembangan strategi yang bertujuan untuk melakukan tindakan mencegah, mengurangi, atau mengoreksi masalahmasalah yang telah diidentifikasi di dalam diagnosa keperawatan.Pada tahap ini dimulai setelah menentukan diagnosa keperawatan dan menyimpulkan rencana dokumentasi

Caring merupakan tindakan perawat yang menunjukan kasih sayang, empati serta ikhlas dalam merawat pasien. Perilaku caring perawat ini bertujuan untuk memberikan asuhan keperawatan melalui suatu pendekatan yang berorientasi pada kepedulian perawat terhadap klien, dimana perilaku caring perawat ini sesuai dengan tuntutan masyarakat yang mengharapkan pelayanan kesehatan yang baik dan berkualitas. Sehingga jika perilaku caring ini diterapkan dengan baik maka klien akan merasa puas dan akan berdampak pada peningkatan mutu pelayanan keperawatan. Pendidikan termasuk salah satu faktor individu yang mempengaruhi perawat dalam berperilaku caring. Pendidikan sangat penting bagi perawat untuk membangun perilaku caring Selain pendidikan, yang termasuk dalam faktor individu selanjutnya adalah pengetahuan. Pengetahuan merupakan hal yang mendasari perawat dalam mengaplikasikan perilaku caring. Semakin tinggi pengetahuan perawat terhadap caring maka harapannya perawat akan semakin tahu sikap yang seperti apa yang bisa menunjukkan dirinya untuk berperilaku caring terhadap klien. Asumsi ini didasarkan karena perawat yang memiliki tingkat kognitif tentang caring yang baik mempunyai landasan teori yang cukup untuk dirinya dalam mempraktekan caring.

Standar praktik keperawatan profesional di Indonesia telah dijabarkan oleh Persatuan Perawat Nasional Indonesia (PPNI) pada tahun 2000. Standar tersebut mengacu pada proses keperawatan yang terdiri atas lima tahap, yaitu pengkajian, diagnosis, perencanaan, implementasi, dan evaluasi 


\section{Metode}

Metode yang digunakan kajian bebas yang bersumber dari berbagai buku dan jurnal sehingga menjadi satu kesatuan kajian bebas. Kajian bebas ini tidak menggunakan variabelvariabel penelitian. Kajian bebas difokuskan dalam berpikir kritis dalam memenuhi kebutuhan pasien.Jurnal ini menggunakan metode perbandingan atau analisis dari berbagai sumber seperti referensi jurnal, buku teks dan e-book. Penulisan jurnal ini melakukan metode perbandingan dan isi yang akan di bandingkan berhubungan dengan konsep dasar asuhan keperawatan dan proses keperawatan. Kajian ini juga dilaksanakan dengan menganalisis artikel-artikel dan jurnal yang berkaitan dengan perencanaan keperawatan. Kajian ini juga menggunakan metode penelitian pustaka, bahan pustaka yang digunakan adalah dengan mengkaji dari berbagai sumber bacaan buku, jurnal, maupun e-book mengenai perencanaan keperawatan. 


\section{Hasil}

Kesadaran masyarakat terhadap mutu pelayanan kesehatan menyebabkan rumah sakit harus memberikan pelayanan dengan baik dan menjaga mutu pelayanan yang diberikan kepada pasien.Salah satu unsur penting dalam pelayanan kesehatan rumah sakit adalah sikap dan pengetahuan perawat.

Sikap dan pengetahuan perawat mempunyai makna yang penting dalam perencaan keperawatan, kurangnya sikap dan pengetahuan perawat profesional dalam melayani klien akan mempengaruhi pelayanan kesehatan dirumah sakit. Faktor-faktor yang mempengaruhi kepatuhan adalah faktor internal meliputi pengetahuan, sikap, kemampuan, motivasi dan faktor eksternal meliputi karakteristik organisasi, karakteristik kelompok kerja,karakteristik pekerjaan, karakteristik lingkungan.

kepatuhan adalah perilaku disiplin dan taat yang mencerminkan nilaipositif, yang harus dimiliki oleh seorang perawat profesional dalammelaksanakan asuhan keperawatan

Perawat yang memiliki sikap positif terhadap karakteristik pekerjaannya akan semakin berorientasi dibidang pekerjaannya, perawat akan menekuninya,berkonsentrasi, disiplin,bertanggungjawab disertai perasaan senang sampai diperoleh hasil yang memuaskan dan tinggikualitasnya 
Pembahasan

Perilaku

Menurut Lawrence Green perilaku ditentukan oleh 3 faktor utama, yakni:

1)Faktor Pendorong (predisposing factors)

Faktor-faktor yang mempermudah atau mempredisposisiterjadinya perilaku seseorang, antara lainpengetahuan, sikap,keyakinan, kepercayaan, nilai-nilai, tradisi, dan sebagainya.

2)Faktor pemungkin (enabling factors)

Faktor-faktor yang memungkinkan atau memfasilitasi perilaku atau tindakan. Yang dimaksud dengan faktor pemungkin adalah sarana dan prasarana atau fasilitas untuk terjadinya perilakukesehatan, misalnya: Puskesmas, Posyandu, Rumah Sakit, tempatpembuangan air, tempat pembuangan sampah, tempat olah raga,makanan bergizi, uang dan sebagainya.

3)Faktor penguat (reinforcing factors)

Faktor yang mendorong atau memperkuat terjadinya perilaku.Kadang-kadang meskipun orang tahu dan mampu untuk berperilaku sehat, tetapi tidak melakukannya.

Sikap

Sikap adalah suatu bentuk evaluasi atau reaksi perasaan.Sikap seseorang terhadap suatu objek adalah perasaanmendukung atau memihak (favorable) maupun perasaan tidak mendukung atautidak memihak (unfavorable) pada objek tersebut. Sikap merupakan semacam kesiapan untuk bereaksiterhadap suatu objek dengan cara-cara tertentu. Dapatdikatakan bahwa kesiapan yang dimaksudkan merupakan kecenderungan potensial untuk bereaksi dengan cara tertentu apabila individu dihadapkan pada suatu stimulus yang menghendaki adanya respon Tingkatan sikap adalah:

(1) Menerima (receiving)

diartikan bahwa orang (subjek) maudan memperhatikan stimulus yang diberikan (objek).

(2) Merespon (responding): memberikan jawaban apabiladitanya, mengerjakan, dan menyelesaikan tugas yangdiberikan adalah suatu indikasi dari sikap, karena dengansuatu usaha untuk menjawab pertanyaan atau mengerjakantugas yang diberikan, terlepas dari pekerjaan itu benar atausalah, adalah berarti bahwa orang menerima ide tersebut. 
(3) Menghargai (valuing) : mengajak orang lain untukmengerjakan atau mendiskusikan suatu masalah adalahsuatu indikasi sikap tingkat tiga.

Perencanaan keperawatan adalah penyusunan rencana tindakan keperawatan yang akan dilakukan untuk mengatasi masalah sesuai dengan diagnosa keperawatan yang telah ditentukan dengan tujuan terpenuhinya kebutuhan pasien

\section{LANGKAH-LANGKAH PERENCANAAN}

Langkah dalam rencana asuhan keperawatan adalah :

- menentukan proritas

- menetapkan tujuan

- menentukan kriteria hasil

\section{Menentukan prioritas}

Dalam menentukan perencanaan perlu disusun suatu sistem untuk menentukan diagnosa yang akan diambil pertama kali. Salah satu sistem yang bisa digunakan adalah hirarki "kebutuhan manusia"(Lyer et al., 1996)

Dengan mengidentifikasi prioritas kelompok diagnosa keperawatan dan masalah kolaburatif, perawat dapat memprioritaskan peralatan yang diperlukan.

Perbedaan antara prioritas diagnosa dan diagnosa yang penting menurut Capernito(2000) adalah :

a. Prioritas diagnosa adalah diagnosa keperawatan atau maslah keperawatan, jiak tidak diatasi saat ini, akan berdampak buruk terhadap keadaan fungsi dan status kesehatan.

b. Diagnosa yang terpenting adalah diagnosa keperawatan atau masalah kolaburatif dimana intervensi dapat ditunda utnuk beberapa saat tanpa bedampak terhadap status fungsi kesehatan.

\section{Menetapkan tujuan}

Tujuan perawatan merupakan pedoman yang luas/umum dimana pasien diharapkan mengalami kemajuan dalam berespon terhadap tindakan.

Tujuan dibedakan menjadi dua, yaitu :

1) Tujuan jangka panjang

Tujuan jangka panjang adalah tujuan yang mengidentifikasi arah keseluruhan atau hasil akhir perawatan. Tujuan ini tidak tercapai sebelum pemulangan. Tujuan jangka panjang 
memerlukan perhatian yang terus menerus dari pasien dan/atau orang lain.

Tujuan yang diharapkan dapat dicapai dalam waktu yang lama, biasanya lebih dari satu minggu atau satu bulan. Kriteria hasil dalam tujuan jangka panjang ditujukan pada unsur "problem/masalah" dalam diagnosa keperawatan.Misalnya : pasien mampu mempertahankan kontrol kadar gula darah satu kali dalam satu minggu selama dua bulan pertama pasca perawatan di rumah sakit.

2) Tujuan jangka pendek

Tujuan jangka pendek adalah tujuan yang harus dicapai sebelum pemulangan. Misalnya : rasa nyeri pasien berkurang/hilang setelah dilakukan tindakan perawatan selama $2 \times 24$ jam. tujuan yang diharapkan bisa dicapai dalam waktu yang singkat, biasanya kurang dari satu minggu.

Tujuan jangka pendek ditujukan pada unsurE/S(etiologi, tanda dan gejala) dalam diagnosa keperawatan aktual/resiko.

\section{Menentukan kriteria hasil}

Tujuan kilen dan tujuan keperawatan adalah standar atau ukuran yang digunakan untuk mengevaluasi kemajuan klien atau ketrampilan perawat. Menurut Alfaro(1994), tujuan klien merupakan pernyataan yang menjelaskan suatu perilaku klien, keluarga, atau kelompok yang dapat diukur setelah intervensi keperawatan diberikan. Tujuan keperawatan adalah pernyataan yang menjelaskan suatu tindakan yang dapat diukur berdasarkan kemampuan dan kewenangan perawat.

Kriteria hasil untuk diagnosa keperawatan mewakili status kesehatan klien yagn dapat dicapai atau dipertahankan melalui rencana tindakan yang mandiri, sehingga dapat membedakan antara diagnosa keperawatan dan masalah kolaburatif. Menurut Gordon(1994), komponen kriteria hasil yang penting dalam kriteria hasil adalah apakah intervensi keperawatan dapat dicapai.

Karakteristik rencana tindakan keperawatan :

a. Konsisten dengan rencana tindakan.

b. Berdasarkan prinsip-prinsip ilmiah(rasional)

c. Berdasarkan situasi individu klien.

d. Digunakan untuk menciptakan suatu situasi yang aman dan terapeutik.

e. Menciptakan suatu situasi pengajaran.

f. Menggunakan saran yang sesuai 
baplpasékeardzandidataasuhan

keperawatan yrgupellam hal yang sangat

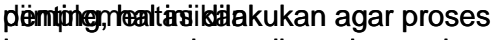

keperawatan dapat dicapai sesuai

dengan yang diharapkan. Perencanaan

keperawatan yang akan disusun harus

mempunyai beberapa komponen, yaitu

\section{Penutupan}

Tahap perencanaan dalam keperawatan merupakan hal yang sangat penting, hal ini dilakukan agar proses keperawatan dapat dicapai sesuai dengan yang diharapkan.

Perencanaan keperawatan yang akan disusun harus mempunyai beberapa komponen, yaitu prioritas masalah, kriteria hasil, rencana intervensi, dan pendokumentasi. Komponenkomponen tersebut akan sangat membantu pada saat proses evaluasi keberhasilan asuhan keperawatan yang telahdiimplementasikan 
Simamora, R. H. (2005). Hubungan Persepsi Perawat Pelaksana Terhadap Penerapan Fungsi Pengorganisasian Yang Dilakukan Oleh Kepala Ruangan Dengan Kinerjanya Diruang Rawat Inap RSUD Koja Jakarta Utara (Doctoral dissertation, Tesis FIK UI, Tidak dipublikasikan).

Daftar Pustaka

Barus, Eva Ranika. "HUBUNGAN PENGETAHUAN DAN SIKAP PERAWAT TENTANG ASKEP DENGAN TINDAKANKELENGKAPAN CATATANKEPERAWATAN DI RSU MITRA SEJATI." JURNAL KEPERAWATAN FLORA 11.1 (2018).

Butar-Butar, J., \& Simamora, R. H. (2016). Hubungan Mutu Pelayanan Keperawatan dengan Tingkat Kepuasan Pasien Rawat Inap di RSUD Pandan Kabupaten Tapanuli Tengah. Jurnal Ners Indonesia, 6(1), 50-63.

Ghofar, Abdul, and Mokhamad Imam Subeqi. "Hubungan antara pengetahuan dan sikap perawat dengan kemampuan teknikal perawat dalam pelaksanaan oral hygiene pada penderita stroke." Eduhealth 5.1 (2015).

Kiran, Yuke, and Umi Sri Puspita Dewi. "Pengetahuan dan Sikap Perawat dalam Memenuhi Kebutuhan Psikologis dan Spiritual Klien Terminal." Jurnal Pendidikan Keperawatan Indonesia 3.2 (2017): 182-189.

Panjaitan, Grace Yolanda. "HUBUNGAN ANTARA INTERVENSI KEPERAWATAN DENGAN KEPUASAN PASIEN." (2019).

Ramadani, Tiara. "PENGETAHUAN DAN SIKAP PERAWAT TERHADAP PERENCANAAN ASUHAN KEPERAWATAN." (2019).

Ramadhaniyah, Eka, Arif Kurniadi, and M. Kom. "KARAKTERISTIK PENGETAHUAN DAN SIKAP PERAWAT TERHADAP PENGISIAN KELENGKAPAN FORMULIR RM 3 (ASUHAN KEPERAWATAN) DI RSUD TUGUREJO SEMARANG TAHUN 2015." (2015).

Simamora, R. H (2005). Hubungan Persepsi Perawat Pelaksana Terhadap Penerapan Fungsi Perorganisasian Yang Dilakukan Oleh Kepala Ruangan Dengan Kinerjanya Diruang Rawat Inap RSUD Koja Jakarta Utara (Doctoral dissertation, Tesis FIK UI, Tidak dipublikasikan)

Situmorang, Augustinus Solagratia. Hubungan pengetahuan dan sikap perawat terhadap kepatuhan skoring early warning score di ruang bethesda rumah sakit umum siloam kupang = the relationship between knowledge and attitude of nurses to compliance of scoring early warning score in bethesda siloam hospitals kupang. Diss. Universitas Pelita Harapan, 2018. 
Utomo, Satrio. Hubungan Antara Pengetahuan Dan Sikap Perawat Dengan

Pendokumentasian Asuhan Keperawatan Di Irna Unit Ortopedi Rsui Kustati Surakarta. Diss. Universitas Muhammadiyah Surakarta, 2007.

Wawan, A dan Dewi, M..Teoridan Pengukuran Pengetahuan, Sikap danPerilaku Manusia. Yogyakarta : Nuha Medika.2010 